\title{
水稲用除草剂「イプフェンカルバゾン」の開発
}

\author{
木戸庸 裕 ${ }^{1, *}$, 沖田洋行 ${ }^{2}$, 岡 村 充 康 ${ }^{3}$, 竹内 崇 ${ }^{3}$, 森田 健 ${ }^{4}$ \\ ${ }^{1}$ 北興化学工業株式会社開発研究所 \\ ${ }^{2}$ 北興化学工業株式会社岡山工場 \\ ${ }^{3}$ 北興化学工業株式会社製品企画部 \\ ${ }^{4}$ 北興化学工業株式会社
}

（2016年6月9日受理）

\section{Development of a rice herbicide, ipfencarbazone}

\author{
Tsunehiro Kido, ${ }^{1}$ Hiroyuki Okita, ${ }^{2}$ Michiyasu Okamura, ${ }^{3}$ Takashi Takeuchi ${ }^{3}$ and Ken Morita ${ }^{4}$ \\ ${ }^{1}$ Central Research Laboratories, Hokko Chemical Industry Co., Ltd., 2165 Toda, Atsugi-shi, Kanagawa 243-0023, Japan \\ ${ }^{2}$ Okayama Factory, Hokko Chemical Industry Co., Ltd., 402 Muneage, Tamano-shi, Okayama 706-0305, Japan \\ ${ }^{3}$ Portfolio Management Department, Hokko Chemical Industry Co., Ltd., \\ 1-5-4 Nihonbashi Honcho, Chuo-ku, Tokyo 103-8341, Japan \\ ${ }^{4}$ Hokko Chemical Industry Co., Ltd., 1-5-4 Nihonbashi Honcho, Chuo-ku, Tokyo 103-8341, Japan
}

Keywords: ipfencarbazone, triazolinone, VLCFA(very-long-chain fatty acids), barnyard grass, Echinochloa spp., paddy rice herbicide.

\section{は じめに}

北興化学工業株式会社は，新規水稲用除草剤の創製に際 し，水田の問題雑草である七エ類（以下，ノビエ）に対して 優れた活性を示し，かつ水稲に対する安全性が高い化合物の 開発を目指し探索合成を開始した.

各種へテロ環をカルバモイル化した化合物を鋭意合成し， 除草活性を評価した結果, 新規な1-アリール-4-カルバモイル 1,2,4-トリアゾリノン誘導体がノビエと各種水田雑草に対し活 性が高いことを見出した。その後, 本系統の最適化を進め, 当初の目標である水稲に対する安全性が高く, 安定した除草 効果を持続するイプフェンカルバゾンを選抜した。本報では イプフェンカルバゾンの研究の経緯, 構造活性相関, 除草特

\footnotetext{
* = 243-0023 神奈川県厚木市戸田2165番地

E-mail: kido-t@hokkochem.co.jp

(c) 日本農薬学会
}

性, 安全性, 代謝分解及び残留についてその知見を報告する。

\section{1. 研 究 の 経 緯}

\section{1. トリアゾリノン系除草剤発見の経緯}

水稲栽培における雑草防除の成否は水稲品質, 収量, 労 力などへ影響を与える. 水田に発生する雑草として,ノビエ が問題なのは依然として変わらず，とりわけヒエ剤は除草剤 として重要な位置づけを有している。本剤の研究を開始した 1990年代は, 農業就業者の減少や高齢化が顕在化し, より省 力的な農業が求められるようになり，水稲用除草剤分野では, 田植同時処理可能な薬剤の開発に期待が高まった。また， ス ルホニルウレア系除草剤を母骫に，ヒ工剂を混合した一発剤 が大きく伸長するなかで, ヒエ剤については処理薬量, 処理 適期幅, ノビエに対する残効性，イネーヒ工選択性の課題が あった，そこで我々は, 低薬量で高葉齢のノビエに対し除草 効果が高く, 長期にノビエの発生を抑え, かつ省力化の観点 から田植同時処理でも水稲に対する安全性が高い独自骨格を 
有するヒエ剂の開発を目指し新規化合物の創製に取組んだ.

Fig. 1にトリアゾリノン系除草剂発見の経緯を示す.

探索当初, 高葉齢のノビエに対して高い除草活性を有し, 長期にノビエの発生を抑える薬剤としてカフェンストロー ル（1）を代表とするカルバモイルスルホニルトリアゾール誘 導体（2）に注目し，主にスルホニル基上の置換基変換を精 力的に行った ${ }^{1)}$. しかし，ノビエに対し活性を示す化合物は あったが，目標に合った化合物を見出すことはできなかった.

そこで, カルバモイル化されたへテロ環構造に注目してカル バモイル-ヘテロ環誘導体（3）を幅広く探索することとした.

文献調査によって見出した 4-置換チオーイソオキサゾリノ ン誘導体 (4) ${ }^{2)}$ は，ノビエに対し除草活性を示すことが確 認されたが，イネに対する安全性が十分でなかった。

そこで，カルバモイル化されたイソオキサゾリノン骨格に 注目し探索した結果，ノビエに対し高い活性を示し，水稲に 対して高い安全性を示す4-アリールイソオキサゾリノン誘 導体（5）を見出した ${ }^{3}$. しかし, 固場条件で 2.5 葉期のノビ
エに対する効果が十分でなく，実用に足る化合物を見出すこ とはできなかった。

次に，4-アリールイソオキサゾリノン誘導体（5）を リードとし，母核であるイソオキサゾリノン環を他のへテ 口環に変換した誘導体（6）の探索を鋭意行った）その結 果, ノビエと各種水田雑草に対し高い活性を示す新規な 1アリール-4-カルバモイル-1,2,4-トリアゾリノン誘導体（7） を見出した ${ }^{4,5)}$.

\section{2. トリアゾリノン誘導体の最適化とイプフェンカルバ ゾンの選抜}

ノビエに対するさらなる活性向上と水稲に対する安全性向 上を目的として，1-アリール-4-カルバモイル-1,2,4-トリア ゾリノン誘導体（7）のベンゼン環の置換基 Xn，カルバモイ ル部位の置換基 $\mathrm{R}^{1}$ および $\mathrm{R}^{2}$ を種々変換し最適化を行った.

1-アリール-4-カルバモイル-1,2,4-トリアゾリノン誘導体 （7）は, Fig. 2 に示した合成スキームに従って合成した ${ }^{6,7)}$.
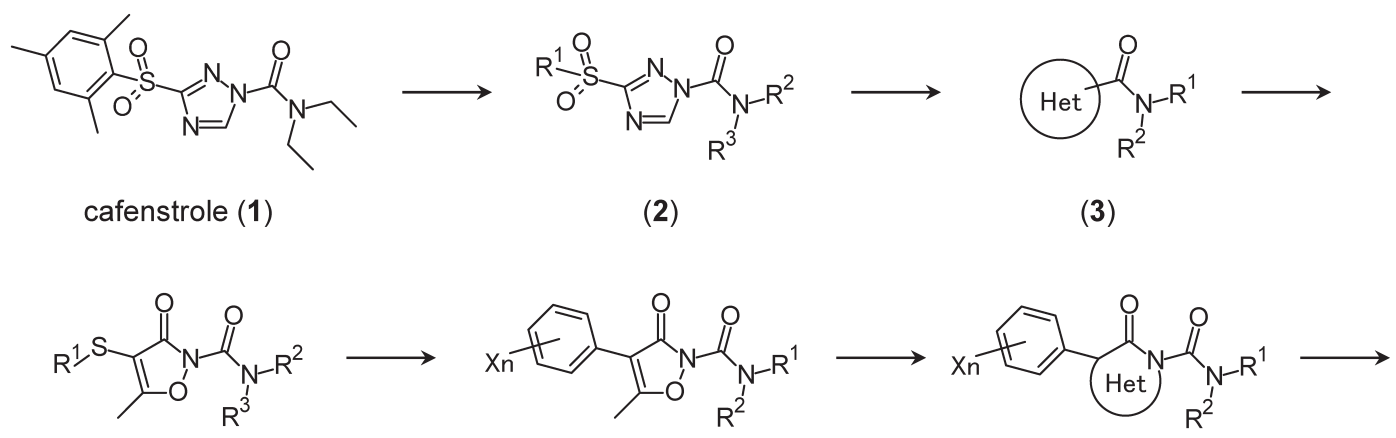

(4)<smiles>[R1]c1ccc(-n2ncn(C(=O)N([R])[R])c2=O)cc1</smiles>

(7)
(5)

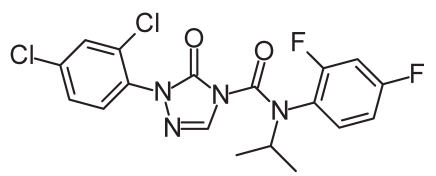

ipfencarbazone (8)

Fig. 1. Process of discovery of triazolinone herbicide.

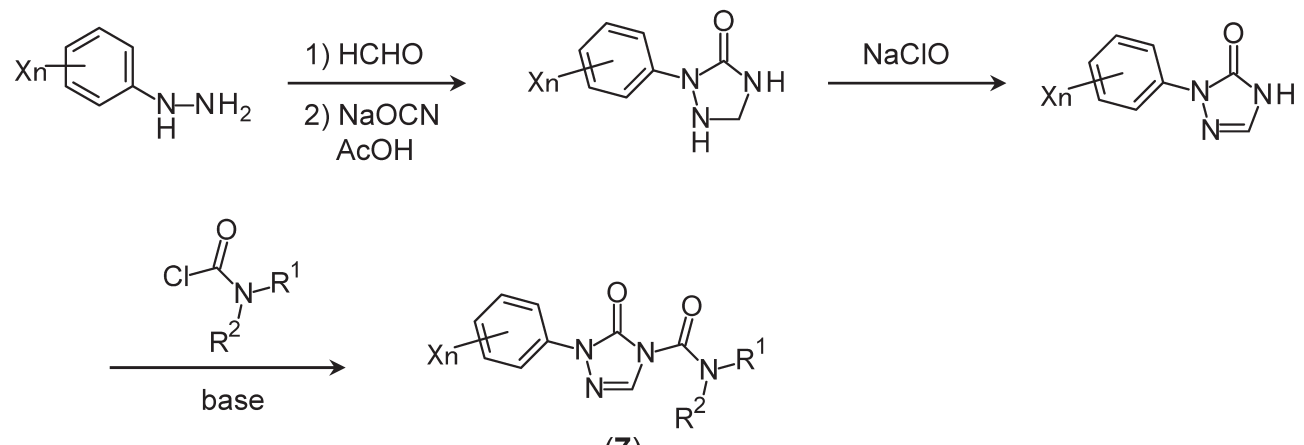

(7)

Fig. 2. Synthetic schemes of 1-aryl-4-carbamoyl-1,2,4-triazolinone derivatives (7). 
Table 1. Structure activity relationship of the triazolinone derivatives

Change of substituent at carbamoyl moiety<smiles>[R]N([R])C(=O)n1cnn(-c2ccccc2)c1=O</smiles>

\begin{tabular}{|c|c|c|c|c|}
\hline \multicolumn{2}{|c|}{ Compound substituents } & \multicolumn{2}{|c|}{$\begin{array}{l}\text { Efficacy on ECHOR } \\
\qquad(80 \text { g a.i./ha })\end{array}$} & \multirow{2}{*}{$\begin{array}{c}\begin{array}{c}\text { Rice injury } \\
(300 \text { ga.i./ha })\end{array} \\
1 \text { DAA }\end{array}$} \\
\hline $\mathrm{R}^{1}$ & $\mathrm{R}^{2}$ & $\begin{array}{c}\text { Pre- } \\
\text { emegernce }\end{array}$ & $\begin{array}{l}\text { Early-Post } \\
\text { emergence }\end{array}$ & \\
\hline $\mathrm{C}_{2} \mathrm{H}_{5}$ & $\mathrm{C}_{2} \mathrm{H}_{5}$ & 1 & 0 & 0 \\
\hline $\mathrm{C}_{2} \mathrm{H}_{5}$ & cyc.-Hex & 2 & 2 & 0 \\
\hline$n-\mathrm{C}_{3} \mathrm{H}_{7}$ & $\mathrm{Ph}$ & 3 & 2 & 0 \\
\hline$i-\mathrm{C}_{3} \mathrm{H}_{7}$ & $\mathrm{Ph}$ & 4 & 3 & 0 \\
\hline $\mathrm{H}_{2} \mathrm{C}=\mathrm{CH}_{5}$ & $\mathrm{Ph}$ & 3 & 2 & 0 \\
\hline $\mathrm{HC} \equiv \mathrm{CCH}_{2}$ & $\mathrm{Ph}$ & 3 & 1 & 0 \\
\hline
\end{tabular}

Growth stage on application: pre-emergence and 1.5 leaves stage of ECHOR. DAA: Days after application, ECHOR: Echinochloa oryzicola, Rice: transplnted 2.2 leaves stage of rice, Index: Herbicidal activity (\% of control), 5: 100-90\%, 4: 89-79\%, 3: 69-50\%, 2: 49-30\%, 1: 29-10\%, 0 : less than $10 \%$.

Table 2. Structure activity relationship of the triazolinone derivatives

Change of substituent on benzene ring of carbamoyl moiety

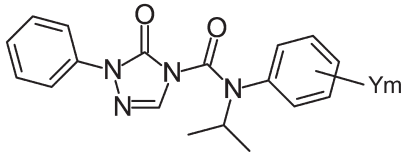

\begin{tabular}{cc}
\hline $\begin{array}{c}\text { Compound } \\
\text { substituents }\end{array} \quad$ Efficacy on ECHOR (80ga.i./ha) & $\begin{array}{c}\text { Rice injury } \\
(300 \text { ga.i./ha })\end{array}$ \\
\hline
\end{tabular}

\begin{tabular}{lccc}
\hline \multicolumn{1}{c}{ Ym } & Pre-emergence & Early-Post emergence & 1 DAA \\
\hline $\mathrm{H}$ & 4 & 3 & 0 \\
$4-\mathrm{Cl}$ & 4 & 3 & 0 \\
$2-\mathrm{F}$ & 3 & 2 & 0 \\
$4-\mathrm{F}$ & 5 & 3 & 0 \\
$2,4-\mathrm{F}_{2}$ & 5 & 5 & 0 \\
$4-\mathrm{CH}_{3}$ & 2 & 1 & 0 \\
$4-\mathrm{CF}_{3}$ & 3 & 1 & 0 \\
$4-\mathrm{CH}_{3} \mathrm{O}$ & 0 & 0 & 0 \\
\hline
\end{tabular}

Table 1から Table 4にトリアゾリノン誘導体の構造活性相 関を示す．活性については，ポット試験におけるノビエに対 する発生前と 1.5 葉期の除草活性, および移植 1 日後のイネ の薬害を示した。

カルバモイル部位の置換基変換について Table 1 と Table 2
Table 3. Structure activity relationship of the triazolinone derivatives

Change of substituent on benzene ring at the 1-position of triazolinone ring

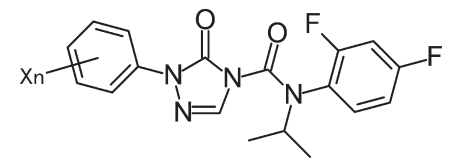

\begin{tabular}{|c|c|c|c|}
\hline \multirow{2}{*}{$\begin{array}{c}\begin{array}{c}\text { Compound } \\
\text { substituents }\end{array} \\
\mathrm{Xn}\end{array}$} & \multicolumn{2}{|c|}{ Efficacy on ECHOR (20 ga.i./ha) } & \multirow{2}{*}{$\begin{array}{c}\begin{array}{c}\text { Rice injury } \\
(300 \text { ga.i./ha })\end{array} \\
1 \mathrm{DAA}\end{array}$} \\
\hline & Pre-emergence & Early-Post emergence & \\
\hline $\mathrm{H}$ & 5 & 4 & 2 \\
\hline $2-\mathrm{Cl}$ & 5 & 5 & 1 \\
\hline $3-\mathrm{Cl}$ & 4 & 3 & 0 \\
\hline $4-\mathrm{Cl}$ & 5 & 4 & 0 \\
\hline $2,4-\mathrm{Cl}_{2}$ & 5 & 5 & 0 \\
\hline $2-\mathrm{CH}_{3}$ & 5 & 5 & 1 \\
\hline $2-\mathrm{CF}_{3}$ & 5 & 4 & 0 \\
\hline $2-\mathrm{CH}_{3} \mathrm{O}$ & 4 & 4 & 0 \\
\hline
\end{tabular}

Table 4. Structure activity relationship of the triazolinone derivatives

Change of substituent at the 3-position of triazolinone ring

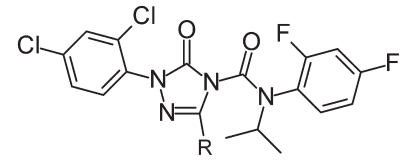

Compound
substituents $\quad$ Efficacy on ECHOR (80ga.i./ha) $\quad \begin{gathered}\text { Rice injury } \\ \text { (300ga.i./ha) }\end{gathered}$

\begin{tabular}{lccc}
\hline \multicolumn{1}{c}{$\mathrm{R}$} & Pre-emergence & Early-Post emergence & $1 \mathrm{DAA}$ \\
\hline $\mathrm{H}$ & 5 & 5 & 0 \\
$\mathrm{CH}_{3}$ & 2 & 1 & 0 \\
$\mathrm{Cl}$ & 0 & 0 & 0 \\
$\mathrm{CF}_{3}$ & 0 & 0 & 0 \\
$\mathrm{CH}_{3} \mathrm{O}$ & 0 & 0 & 0 \\
\hline
\end{tabular}

に示す。ジエチルカルバモイル基や $N$-シクロヘキシル- $N$-エ チルカルバモイル基の導入では高い除草活性を示さなかっ た.フェニル基の導入によって発生前のノビエに対する活 性が向上し， N-イソプロピル-N-フェニルカルバモイル基は 1.5 葉期のノビエに対しても活性が向上した.

次にカルバモイル部位の窒素原子上の置換基をイソプロピ ルと置換フェニルに固定し, ベンゼン環の置換基変換を行っ た.フッ素の導入, 特に2,4-ジフッ素の導入は, ノビエに対 して著しく活性を向上させた，一方，メチル基，トリフルオ ロメチル基，メトキシ基の導入によって活性は低下した。 
次にトリアゾリノン環 1 位のベンゼン環の置換基変換を 行った. (Table 3). 塩素の導入によってノビエに対する活性 が向上，あるいはイネに対する薬害が軽減し，特に，2,4-ジ クロロ体は, 発生前と 1.5 葉期のノビエに対して極大の活性 を示し，イネに対する薬害は認められなかった。また，オル ト位にメチル基, トリフルオロメチル基, メトキシ基が置換 しても高い除草活性を示すことが解り，ベンゼン環の2位に 置換基を有することが高い除草活性の発現に重要であること が示唆された。

また，トリアゾリノン環の3位の置換基効果について検討 した（Table 4).メチル置換体はノビエに対して若干の活性 を示したものの, 塩素原子置換体, トリフルオロメチル置換 体，およびメトキシ置換体は活性を示さなかった。

これら 1-アリール-4-カルバモイル-1,2,4-トリアゾリノン誘 導体（7）の水稲用除草剂としての作用特性を詳細に検討した 結果, 当初の目標である 2.5 葉期のノビエに対し効果が高く, 長期間安定した除草効果を示し，水稲に対する安全性が高い イプフェンカルバゾン（8）を最適化合物として選抜した ${ }^{8)}$.

\section{2. 名称および性状}

Common name (ISO Name): ipfencarbazone

Development Code: HOK-201

Chemical Name (IUPAC):

1-(2,4-dichlorophenyl) -2', $4^{\prime}$-difluoro-1,5-dihydro- $N$ isopropyl-5-oxo-4H-1,2,4-triazole-4-carboxanilide

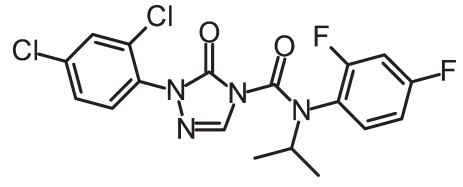

Fig. 3. Chemical structure of ipfencarbazone.
Commercial Name: FIGHTER ${ }^{\circledR}$

CAS No.: 212201-70-2

Molecular Formula: $\mathrm{C}_{18} \mathrm{H}_{14} \mathrm{Cl}_{2} \mathrm{~F}_{2} \mathrm{~N}_{4} \mathrm{O}_{2}$

Molecular Weight: 427.23

Appearance (physical state, form and color):

Solid, Fine powder, White to Off-white

Melting Point: $133.8-137.3^{\circ} \mathrm{C}$

Solubility (water): $0.515 \mathrm{mg} / \mathrm{L}\left(20^{\circ} \mathrm{C}\right)$

$\log P_{\text {ow }}: 3.0\left(25^{\circ} \mathrm{C}\right)$

\section{3. 水稲用除草剤としての作用特性}

\section{1. イプフェンカルバゾンの除草活性}

イプフェンカルバゾンは，ノビエに高い活性を有する9． 単剤の標準薬量 $250 \mathrm{~g}$ a.i./haは, ノビエの発生前から 2.5 葉期 まで効果を示すとともに, 発生前から発生始期までのアゼ ナ類, コナギ等の一年生広葉雑草, 一年生カヤツリグサ科雑 草およびイヌホタルイ, ミズガヤツリ等の多年生雑草に対し ても有効である（Table 5)。 また, 発生前のノビエに対する $\mathrm{EC}_{50}$ 值は $0.0023 \mathrm{ppm}$ であり ${ }^{10)}$, 極低濃度で作用する事が確 認された（Fig. 4).

\section{2. イプフェンカルバゾンの残効性}

戋場における残効期間を検討した結果 ${ }^{11)}$, イプフェンカ ルバゾンは中干し以降も高い除草効果を発揮し, 自然発生の ノビエに対し約70日間の残効が認められた（Fig. 5).

\section{3. イプフェンカルバゾンの移植水稲に対する安全性}

水稲に対する安全性を確認するため, イプフェンカルバゾ ンの標準薬量（250 g a.i./ha）を水稲移植直後, 移植 5 日後, 移植 10 日後に処理した ${ }^{9)}$. いずれの処理時期においても水 稲に対する影響はほとんど認められなかった（Fig. 6).ま

Table 5. Hebicidal activity on ipfencarbazone

\begin{tabular}{|c|c|c|c|c|c|c|c|c|c|}
\hline \multirow{3}{*}{ Application timings } & \multirow{3}{*}{$\begin{array}{c}\text { Dose } \\
\text { (g a.i./ha) }\end{array}$} & \multicolumn{8}{|c|}{ Herbicidal activity } \\
\hline & & \multicolumn{4}{|c|}{ Annual weeds } & \multicolumn{4}{|c|}{ Perennial weeds } \\
\hline & & ECHOR & MOOVA & LIDPY & CYPDI & SCPJO & CYPSE & SAGPY & SAGTR \\
\hline \multirow[t]{2}{*}{ Pre-emergence } & 250 & 100 & 100 & 98 & 100 & 100 & 100 & 10 & 0 \\
\hline & 125 & 100 & 100 & 95 & 98 & 100 & 100 & 0 & 0 \\
\hline \multirow[t]{2}{*}{ Early-Post emergence } & 250 & 100 & 90 & 90 & 90 & 100 & 70 & 0 & 0 \\
\hline & 125 & 100 & 80 & 80 & 75 & 85 & 50 & 0 & 0 \\
\hline
\end{tabular}

Rating scale: 0 (no effect )-100 (completely effective).

ECHOR: Echinochloa oryzicola, MOOVA: Monochoria vaginalis, LIDPY: Lindernia procumbens, CYPDI: Cyperus difformis, SCPJO: Scirpus juncoides var. ohwianus, CYPSE: Cyperus serotinus, SAGPY: Sagittaria pygmaea, SAGTR: Sagittaria trifolia.

*Growth stage on application: pre-emergence and 2.5 leaves stage of ECHOR. Early-Post emergence of other weeds are 2 leaves or 2 pair stage application. 


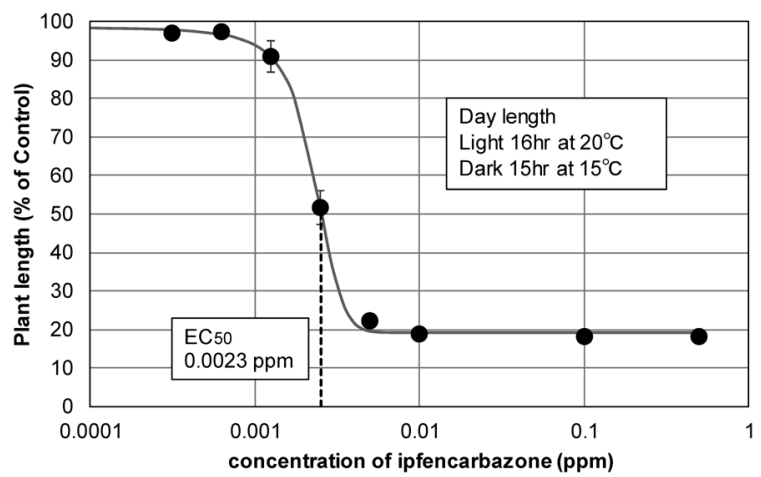

Fig. 4. Efficacy of ipfencarbazone against pre-emergence Echinochloa spp. Assesment: Measurement of plant length at 10 days after application.

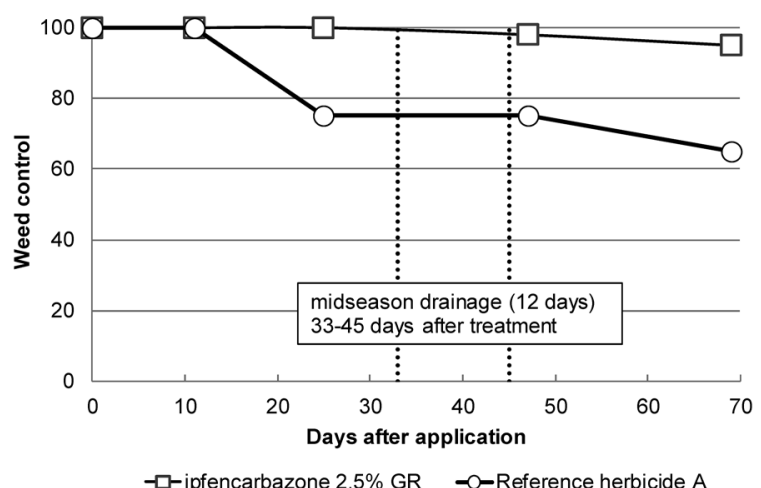

Fig. 5. Residual activitiy of ipfencarbazone against Echinochlor spp. at dosage of $250 \mathrm{~g}$ a.i./ha in the field. Rating scale: 0 (no effect)-100 (completely effective).

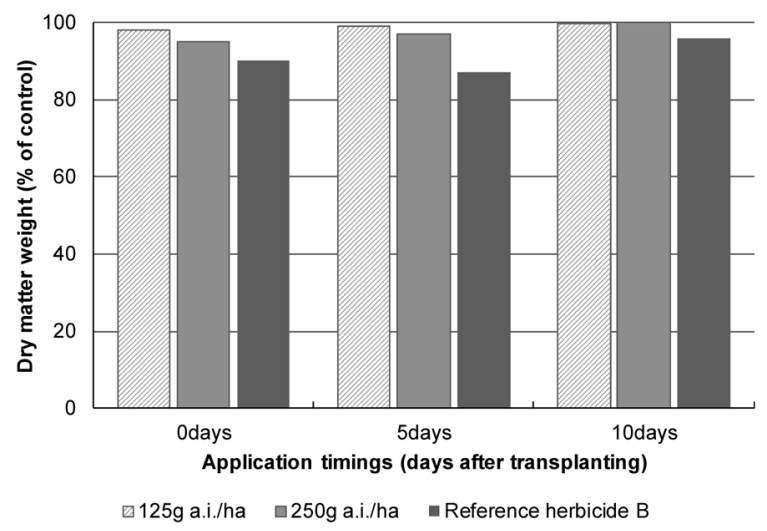

Fig. 6. Rice crop safety of ipfencarbazone at diffarent application timings. Assesment: Measurement of dry matter weight at 28 days after application.

た, 移植深度, 土袞の違い, 漏水の有無, 水稲品種の違いに よる影響を検討した結果，その影響は極軽微であり水稲に対 する高い安全性が示された ${ }^{12-14)}$.

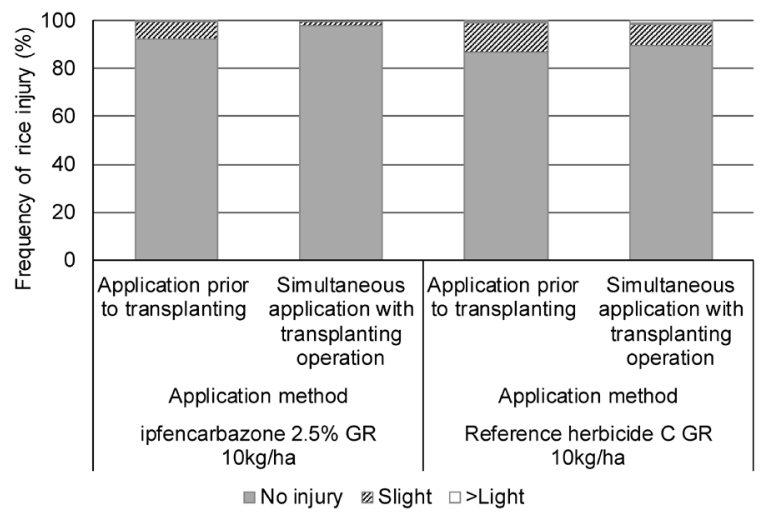

Fig. 7. Crop safety of ipfencarbazone applied at 0 days after or prior to transplanting.

Table 6. Distribution of ipfencarbazone in soil (field test)

\begin{tabular}{|c|c|c|c|c|c|}
\hline \multirow{3}{*}{ Soil texture } & \multirow{3}{*}{$\mathrm{pH}$} & \multirow{3}{*}{$\begin{array}{c}\text { Organic carbon } \\
\text { content }(\%)\end{array}$} & \multicolumn{3}{|c|}{$\begin{array}{l}\% \text { of distribution of } \\
\text { ipfencarbazone in soil }\end{array}$} \\
\hline & & & \multicolumn{3}{|c|}{ Soil layer from soil surface } \\
\hline & & & $0-2 \mathrm{~cm}$ & $2-5 \mathrm{~cm}$ & $5-10 \mathrm{~cm}$ \\
\hline Light clay & 6.4 & 3.3 & 91 & 6 & 3 \\
\hline
\end{tabular}

Application rate: $250 \mathrm{~g}$ a.i./ha.

Soil sampling date: 69 days after application.

Ipfencarbazone was extracted by acetone.

Table 7. Translocation of herbicide in soil and herbicidal activity on percent ECHOR control by Leaching test

\begin{tabular}{|c|c|c|c|c|c|}
\hline \multirow{3}{*}{ Soil texture } & \multirow{3}{*}{$\mathrm{pH}$} & \multirow{3}{*}{$\begin{array}{c}\text { organic carbon } \\
\text { content }(\%)\end{array}$} & \multicolumn{3}{|c|}{$\%$ ECHOR* control } \\
\hline & & & \multicolumn{3}{|c|}{ Soil layer from soil surface } \\
\hline & & & $0-1 \mathrm{~cm}$ & $1-2 \mathrm{~cm}$ & $2-3 \mathrm{~cm}$ \\
\hline Sandy loam & 5.7 & 2.7 & 96 & 7 & 1 \\
\hline Clay loam & 5.7 & 7.2 & 100 & 1 & 0 \\
\hline Light clay & 6.4 & 3.3 & 100 & 5 & 0 \\
\hline Heavy clay & 6.0 & 6.1 & 100 & 1 & 0 \\
\hline
\end{tabular}

*ECHOR: Echinochloa oryzicola. Application rate: $250 \mathrm{~g}$ a.i./ha. Soil partitioning method, Leaching paddy water from pot: $2 \mathrm{~cm} /$ day, for 3 days. Assesment: Measurement of plant length at 20 days after seeding.

\section{4. イプフェンカルバゾン剂の田植同時処理}

田植同時処理剤の適用性を判断するため，実用場面を想定 した田植同時処理や移植直前処理（田植同時処理時に薬剤が 移植前の条にドリフトする状況を想定）の条件で水稲に対す る影響を確認した ${ }^{11)}$ ．その結果，いずれの処理でも安全性が 高く, 実用上問題となる薬害は認められなかった（Fig. 7). 


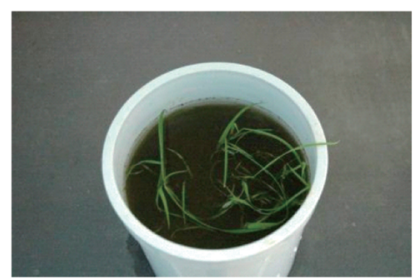

7 days after application

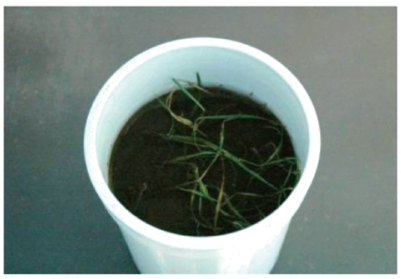

14 days after application

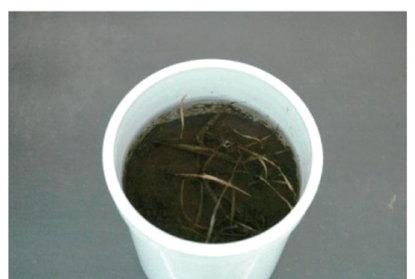

21 days after application

ipfencalbazone $250 \mathrm{ga}$.i./ha application at 2.5 leaf stage of Echinochlor spp.

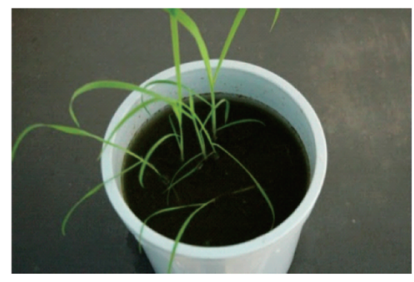

7 days

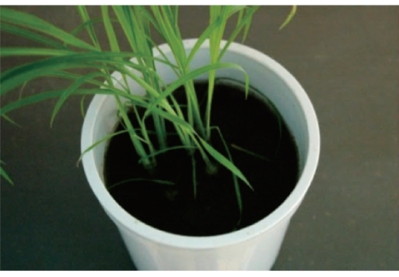

14 days

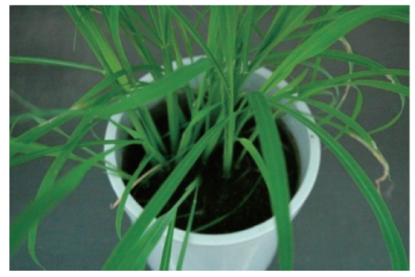

21 days

Untreated control

Fig. 8. Effect on Echinochloa spp. by ipfencarbazone application.

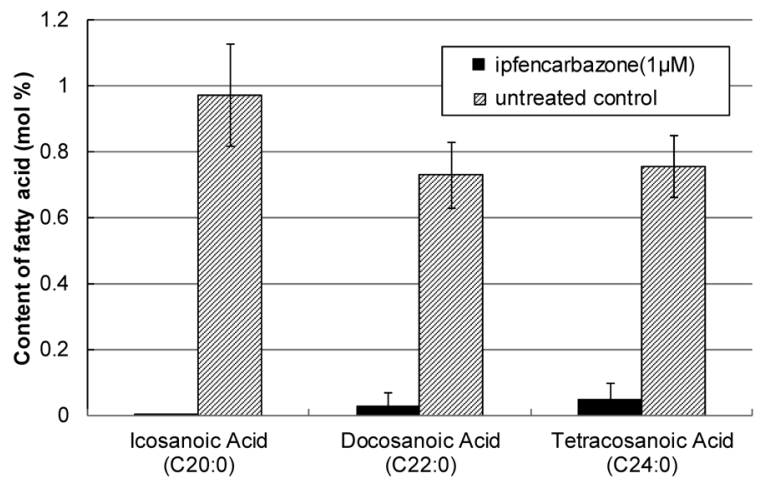

Fig. 9. Determination of total lipid as fatty acid in leaves and shoots of Echinochloa oryzicola. by ipfencalbazone application.

\section{5. 土壤中移行性}

围場に処理したイプフェンカルバゾンの土袞中移行性確 認するために層別に薬剤を分析した結果，表層から $2 \mathrm{~cm}$ ま での層に $90 \%$ 以上存在することが明らかとなった ${ }^{10)}$. また, 土壌別の移行性についてノビエを用いて検定した結果，イプ フェンカルバゾンは, ノビエの抑制率から, 土壌の種類（重 埴土，埴壌土，軽埴土，砂壌土）に関わらず，その多くは 表層から $1 \mathrm{~cm}$ までの層に存在すると推察された ${ }^{9)}$ (Table 6, Table 7).

\section{6. イプフェンカルバゾンの殺草症状および作用機構}

イプフェンカルバゾンが処理されたノビエは, 生育抑制が 認められ, 茎葉の濃緑化, 出すくみ, 捻転などの症状をとも ない枯死に至る (Fig. 8) ${ }^{9,15)}$. また, イプフェンカルバゾン
の吸収部位を確認した試験では, 主に根部および茎葉基部か ら吸収されていると推定された。

イプフェンカルバゾンの作用機構はノビエに対する殺草症 状から極長鎖脂肪酸の生合成阻害と推定している. 本剂を吸 収したノビエは, 植物体内における炭素数 20 以上の脂肪酸 含有量が減少することが確認されており（Fig. 9)，このこと は, 脂肪酸の伸長反応を阻害していると推察される ${ }^{15,16)}$. 今 後, 伸長反応阻害の詳細なメカニズムについてさらに検討を 行う予定である.

\section{4. イプフェンカルバゾンの安全性}

\section{1. 人畜毒性}

イプフェンカルバゾン原体および製剤は哺乳動物に対して いずれの暴露経路においても急性毒性は弱く, 毒物あるいは 劇物に相当しない. 刺激性は原体および製剤ともに眼で極軽 度で, 皮膚感作性は原体で軽度であった。慢性毒性, 発がん 性, 繁殖への影響及び催奇形性や変異原性の試験でも安全性 に問題はないと確認された（Table 8).

\section{2. 環境生物に及ぼす影響}

イプフェンカルバゾンの鳥類, 魚介類及び有用昆虫に対す る毒性は弱かった。藻類に対しては生長阻害作用が観察され たが, 通常の使用条件下において, 環境中で悪影響を及ぼす ものではないと考えられた。

\section{3. 代謝分解および残留}

${ }^{14} \mathrm{C}$ 標識イプフェンカルバゾンをラットに経口投与した結 
Table 8. Toxicological data of ipfencarbazone

\begin{tabular}{lll}
\hline \multicolumn{1}{c}{ Study } & \multicolumn{1}{c}{ Animal } & \multicolumn{1}{c}{ Results } \\
\hline Acute oral & Rat & $\mathrm{LD}_{50}:>2000 \mathrm{mg} / \mathrm{kg}(\mathrm{M}, \mathrm{F})$ \\
& Mouse & $\mathrm{LD}_{50}:>2000 \mathrm{mg} / \mathrm{kg}(\mathrm{F})$ \\
& Rat & $\mathrm{LD}_{50}:>2000 \mathrm{mg} / \mathrm{kg}{ }^{\mathrm{a})}(\mathrm{F})$ \\
Acute dermal & Rat & $\mathrm{LD}_{50}:>2000 \mathrm{mg} / \mathrm{kg}(\mathrm{M}, \mathrm{F})$ \\
& Rat & $\mathrm{LD}_{50}:>2000 \mathrm{mg} / \mathrm{kg}{ }^{\mathrm{a})}(\mathrm{M}, \mathrm{F})$ \\
Acute inhalation & Rat & $\mathrm{LC}_{50}:>5.9 \mathrm{mg} / \mathrm{L}(\mathrm{M}, \mathrm{F})$ \\
Eye irritation & Rabbit & $\mathrm{Very} \mathrm{slightly}$ \\
Skin irritation & Rabbit & Very slightly \\
& Rabbit & Non-irritant \\
Skin sensitization & Rabbit & Non-irritant \\
& Guinea pig & Slightly \\
Teratogenicity & Guinea pig & Negative \\
Mutagenicity & in vitro, in vivo & Negative \\
\hline
\end{tabular}

a) $2.5 \%$ Granule

果, 投与 168 時間後までに大部分が代謝, 排泄された。移植 水稲への処理では, 可食部への移行は極めて低いレベルで あった．イプフェンカルバゾンは動物体内，植物中でカル バモイル部の開裂，水酸化等を経て分解し，さらに抱合化反 応が見られた。土㙵中や水中光分解では，カルバモイル部の 開裂後さらに分解し，炭酸ガスにまで無機化された．移植水 稲における作物残留試験の結果，玄米および稲わら中にイプ フェンカルバゾンは検出されなかった。 また，水田戋場にお ける土袞中半減期は 8.5〜34.4日であった ${ }^{17,18)}$.

\section{おわりに}

弊社では, 新たな水稲用除草剂を開発するにあたり, 新規 トリアゾリノン誘導体を見出し，ノビエに対する高い効果と 長期残効性，また，水稲に対する高い安全性を併せ持ち，七 エ剂として優れた特性を有するイプフェンカルバゾンを選抜 した．本剂はこれらの特性を活かした田植同時処理可能な薬 剤として，2008年より公的委託試験を開始し，2013年 8月 6日，イプフェンカルバゾン単剤「ファイター ${ }^{\circledR} x_{n} 」$ ，および

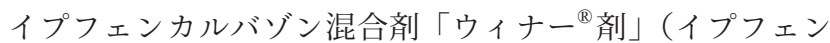
カルバゾン・ブロモブチド・ベンスルフロンメチル混合剤）

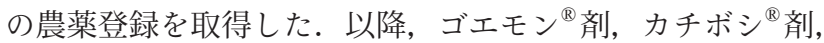

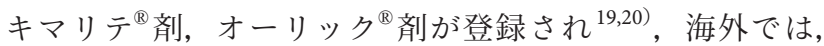
大韓民国でイプフェンカルバゾン混合剤を販売している，今 後さらに新たな混合㓮が開発され，普及面積は拡大すると期 待している。我が国の水稲栽培場面における実用的農薬とし て，今後も現場のニーズに合致した優れた性能を有する混合 剂の開発を継続し，農業生産に貢献していきたい。

\section{謝辞}

イプフェンカルバゾンの開発，上市にあたっては，公的試 験を通じ，公益財団法人日本植物調節剂研究協会を始め, 都 道府県の農業試験場, 国立研究開発法人農業・食品産業技術 総合研究機構の各研究センター, 一般財団法人残留農薬研究 所, 筑波大学, 埼玉大学, 東京工業大学など多くの関係機関 に御指導，ご支援を頂きました。さらには，イプフェンカル バゾン含有製品の開発, 販売に際しては, 住友化学株式会 社, 住化アグロソリューションズ株式会社, 全国農業協同組 合連合会, デュポン株式会社, バイエルクロップサイエンス 株式会社にご支援を頂きました（50音順）。なお，本剂の研 究開発においては, 著者らの研究のみならず，多くの弊社社 員も携わり協力を得たことは言うまでもなく, 関係者の方々 にも心から感謝申し上げます。

\section{引 用 文 献}

1) 石川弘道, 梅田 天, 木戸庸裕, 高井紀行, 吉沢裕和（北興化学 工業)：特開平 5-140125 (1993)

2）水貝宗治, 佐藤一雄, 閒谷淳二, 本間豊邦（三共株式会社）：特 開平 5-39275 (1993)

3) 森田 健, 大野利治, 木戸庸裕, 平山一雄, 沖田洋行, 渡邉嘉 久, 吉澤裕和, 尾上雅英（北興化学工業）：WO98/11079 (1998)

4) 木戸庸裕, 沖田洋行, 竹内 崇, 岡村充康, 森田 健: 日本農薬 学会第 29 回大会講演要旨集, p. 58, 2004.

5）森田 健, 木戸庸裕, 平山一雄, 沖田洋行, 大野利治, 渡邊嘉 久，尾上雅英（北興化学工業）：特許第 3728324 号（2005）。

6）木戸庸裕, 大野利治, 沖田洋行, 森田 健, 楠 雅幸, 保原 智 (北興化学工業)：特許3863736号 (2006).

7) 沖田洋行, 木戸庸裕 (北興化学工業)：特許第4397579号 (2009).

8）木戸庸裕, 沖田洋行, 岡村充康, 近藤 智, 竹内 崇, 森田 健：日本農薬学会第 33 回大会講演要旨集, p. 36, 2008.

9）岡村充康, 近藤 智, 本間百合子, 竹内 崇, 武富 巖, 木戸庸 裕, 沖田洋行, 森田 健: 日本農薬学会第 33 回大会講演要旨集, p. 37,2008

10）兼松 慧, 秋山美佐紀, 平松基弘：日本農薬学会第39回大会講 演要旨集, p. 75, 2014.

11）兼松 慧, 小山公平, 菱池宣弘, 高畑好之, 竹内 崇：日本農薬 学会第38回大会講演要旨集, p. 74, 2013.

12）笠原達矢, 竹内 崇, 岡村充康, 木戸庸裕, 沖田洋行 : 日本農薬 学会第 35 回大会講演要旨集, p. 91, 2010.

13）笠原達矢, 竹内 崇, 岡村充康, 高畑好之: 日本農薬学会第 36 回大会講演要旨集, p. 72, 2011.

14）小山公平, 兼松 慧, 笠原達矢, 竹内 崇, 高畑好之, 岡村充 康：日本農薬学会第 37 回大会講演要旨集, p. 114, 2012.

15）近藤 智, 竹内 崇, 岡村充康, 木戸庸裕, 沖田洋行, 松 本 宏, 兒井健二：日本農薬学会第 34 回大会講演要旨集, p. 64, 2009.

16）近藤 智，木戸庸裕，西田生郎，太田啓之：日本農薬学会第 38 
回大会講演要旨集, p. 104, 2013.

17) 北折和彦, 高瀬洋平, 秋山美佐紀, 神長聡子, 小村智博, 高井紀 行：日本農薬学会第 38 回大会講演要旨集, p. 143, 2013.

18) 高瀬洋平, 北折和彦, 秋山美佐紀, 神長聡子, 小村智博, 高井紀 行：日本農薬学会第 38 回大会講演要旨集, p. 148, 2013.

19) 高畑好之, 竹内崇（北興化学工業）：特許第4212734号 (2008).

20) 竹内 崇, 岡村充康, 渡邊 司, 木戸庸裕 (北興化学工業) : 特 許第4609910号 (2010).

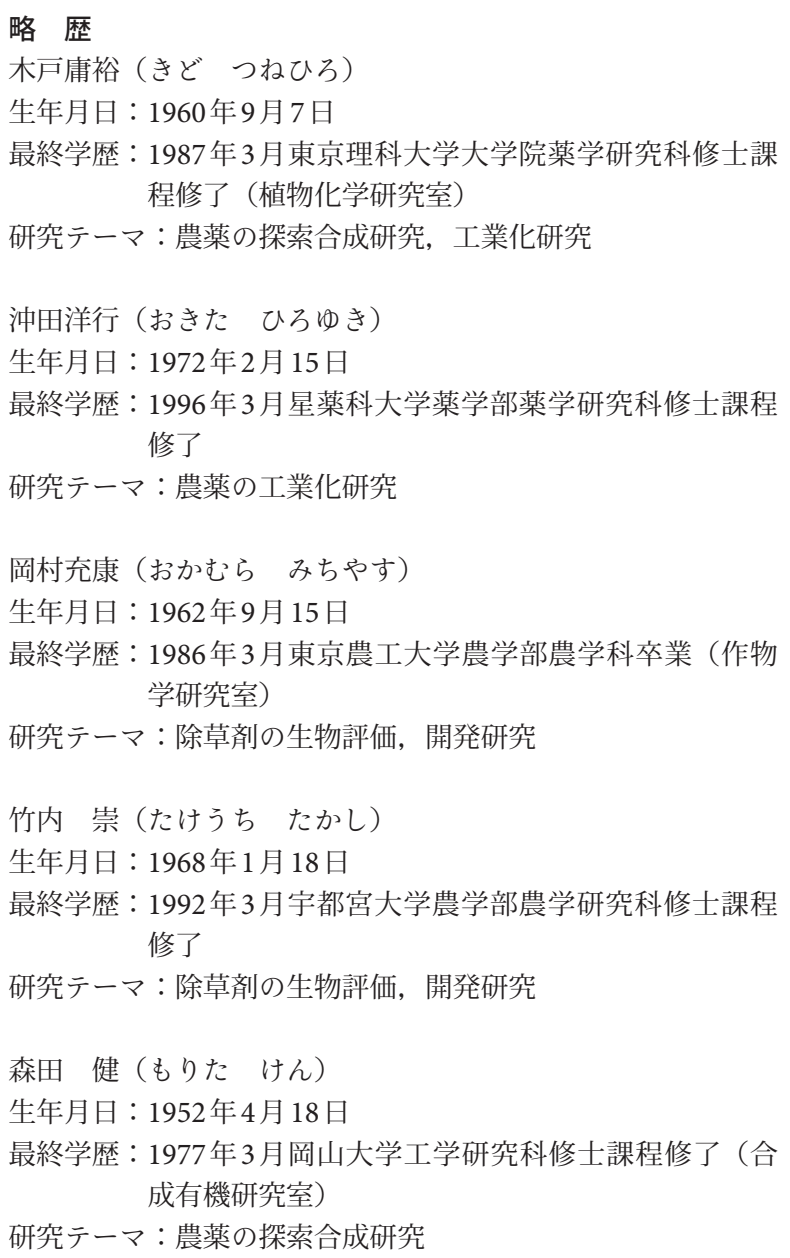

